\title{
The New Recycling: Economic Theory, IMF Conditionality and Balance of Payments Adjustment in the 1980s
}

\section{Philip Daniel}

\section{Introduction}

The first and second 'oil shocks', and the current inflationary recession, have spawned a considerable literature on the process of balance of payments adjustment in the non-oil exporting low and middle income countries (ldcs). The subject has been the focus of attention for numerous expert groups convened by international organisations. There is now a range of proposals for improving the mechanisms for recycling surpluses and counteracting deficits, and a number of new initiatives within the international organisations are already taking shape. This article is addressed to an implication of the process which has received surprisingly limited attention: the growing importance of the particular models of economic structure and policy which underly adjustment programmes. It will be argued that new proposals for international recycling and adjustment mechanisms could prove disadvantageous for ldes unless renewed consideration is given by the ldes themselves, international organisations, and sympathetic development economists, to the short and medium term macro-economic policy that underpins any development strategy.

The International Monetary Fund has commonly imposed pre-conditions and performance criteria for its lending to member countries in support of balance of payments adjustment. By this means, and through its regular consultations with governments and monetary authorities, the Fund has been instrumental in developing and propagating a view of economic structure and policy which may broadly be termed 'monetarist'. The term 'monetarist' is not employed here pejoratively, and the sense in which it may be applied to Fundsupported programmes is defined below. It is argued here that this view is growing in importance because the Fund's role in balance of payments financing is once again expanding, and because the proportion of Fund facilities which involve terms of strict conditionality has dramatically increased in recent years.

Conflict between the prescriptions of the IMF and the apparent goals and policies of ldes has a long history. To some extent the conflict has been contrived: governments, or factions within governments, often prefer to blame the imposition of unpopular economic measures upon some outside agency, even when they

'The author wishes to thank Stephany Griffith-Jones, Charles Harvey. Dudley Seers, Ron Dore and Chris Colclough for their help by way of comments and discussion. recognise the need for such measures. Nevertheless, the conflict has been real enough to lead some governments to avoid recourse to the Fund, or to break off negotiations and forego needed balance of payments support. In Latin America, local experience led to the development of a detailed critique of Fundsponsored stabilisation programmes, based on the 'structuralist' approach to economic analysis and policy. It was argued that the Fund's approach was biased in favour of foreign investors and lenders, and against lower-income groups and long-term national development. Criticism drawn from this strand of thinking continues to influence discussion of conditionality and adjustment programmes. It is argued here that such criticism has tended to ignore the central place of a particular brand of economic theory in Fund-supported programmes, and to underplay the importance of a short and medium-term macroeconomic policy framework in mounting alternatives to such programmes. This has sustained a series of unproductive 'vicious circles' which now inhibit effective lending programmes through multilateral institutions in support of balance of payments adjustment at a time when they are most needed.

\section{Financing the Deficits - Recent Experience}

The financing of the non-oil ldc current account deficits that appeared after the 1973-74 oil price rise led to a substantial increase in the proportion of private debt among total financing flows. The proportion of non-debt-creating flows (ie direct private investment and transfers, including grant aid) fell from nearly half the total of $\$ 21$ bn in 1973 to under one third of the total of $\$ 69$ bn by 1979 . Similarly, the proportion of official loans dropped from nearly 27 per cent to just under 21 per cent over the same period. Long term private debt, on the other hand, increased from just under 27 per cent to nearly 44 per cent of the total International Monetary Fund 1981a:129, Table 23; the totals referred to include current account deficits and reserve increases].

There was a corresponding change in the structure of ldc indebtedness [International Monetary Fund 1981a:132, Table 27]. By 1979, private creditors accounted for 58 per cent of total outstanding debts of $\$ 322$ bn; by comparison 29 per cent was accounted for by governments and 13 per cent by international institutions. Private creditors had accounted for just under 50 per cent in 1973. 
The important role of private financial institutions in recycling after the first oil shock is obvious. But is it likely to continue to grow?

There is some evidence that the position is already changing. In 1980 and in 1981 (according to IMF forecasts) the proportion of private long-term debt in total current account finance has fallen sharply, while official loans have recovered to about a quarter of the total. There has also been a sudden rise in "other financing flows' in 1980 and 1981: this category includes both short term flows and certain IMF and bilateral monetary authority transactions. Private long-term debt - in forms such as eurodollar syndicated credits and bond issues-is now diminishing in relative importance as a source of finance to deal with renewed balance of payments problems.

The emergence of this pattern coincides with widespread reappraisal of the role of private financial institutions in balance of payments financing, and with new initiatives aimed at increasing the contribution of international institutions to the adjustment process. ${ }^{2}$ Five elements can be discerned in this reappraisal. First, it is acknowledged that the recent sharp rise in current account deficits of ldes is a product not only of the latest round of oil price increases, but also, in part, of policy-induced recession in Western industrialised countries and the increased cost of servicing past loans. The rise of dollar interest rates to record levels has greatly added to the debt-service burden of those countries that resorted to private long-term capital markets in the 1970s, and is thus an important cause of the new financing requirements. (Since much of the debt was contracted in the form of loans at variable interest rates.) Second, there has been criticism of private banks as recycling agents on a number of grounds, the most important of which is that the distribution of loans that has resulted from the banks' involvement has favoured middle-income and newlyindustrialising countries (NICs). Killick [1981:98] has estimated that at the end of $1979,99.7$ per cent of the net flow of Euromarket lending (ie claims minus liabilities) was accounted for by just five countries: Argentina, Brazil, Liberia, Mexico and South Korea. Thus there is a strong case for alternative arrangements in the interests of low income countries. Third, there is some doubt that the private banks will themselves wish to continue to function as the major recycling agents. Before 1974 their lending pre-occupations were for trade credit and project finance, not for balance of payments support. With increased risk of default, and growing incidence of rescheduling

${ }^{2}$ For more complete discussion of these points see. for example. Dell and Lawrence 1980; Griffith-Jones 1980a. 1980b; Killick 1981; a fortncoming monograph by Arjun Sengupta and Frances Stewart for the Centre for Research on the New International Economic Order will also address both diagnosis and cure. requirements, it is probable that the banks will be seeking some official/international complement to their own efforts. The IMF itself asserts that one function of its programmes is to act as a catalyst for the provision of more private credit to ldcs. Fourth, the surplus countries (especially OPEC) have shown signs of a similar wish to diversify the mechanisms of recycling. This is not to say that they are withdrawing funds from the international banking system, but rather that they are seeking additional avenues through which to achieve secure investment of surpluses, an effective contribution to recycling, and enhanced political influence. The most obvious example is the \$8 bn loan from Saudi Arabian Monetary Authority to the IMF, signed in May 1981 [IMF 1981 b; GriffithJones 1981). Fifth, there is a growing awareness that the relative strength of the international financial institutions (especially the IMF and the World Bank) was actually diminished by the circumstances of the 1970s, and that it should either be revived or supplemented by new international arrangements.

The World Bank was constrained by its Articles of Association from extending its financing arrangements much beyond project lending, while the IMF was restricted by insufficient increases in quotas or issues of Special Drawing Rights. Since all IMF lending is a fixed multiple of country quotas, the fact that, in 1979 , a sixfold increase in quotas would have been required to restore their ratio to the volume of world imports to its level at the inception of the IMF, is a dramatic indicator of the decline in the Fund's relative importance [estimated by Dell and Lawrence 1980|. This also means that the international linkage between financing of deficits and domestic adjustment was not strengthened during the 1970s, since private banks and bilateral official donors did not usually impose explicit conditions about domestic economic management upon borrowers. Concern at the implications of lack of conditionality has grown in Western industrialised countries; for example, in commenting on the possibility of increased financing via the IMF and the World Bank, after his return from Fund/World Bank meetings in Libreville, Gabon in May 1981, the Governor of the Bank of England, Sir Gordon Richardson, has said:

although these various sources of finance for developing countries are being promoted and enlarged, it was an important strand of thinking at Libreville that such lending should continue to be accompanied by appropriate programmes for economic adjustment. This implies that the integrity of IMF conditionality should be maintained, and that World Bank lending should be attuned to the adjustment needs as well as the longer-term development needs of the borrowing countries.

[Bank of England 1981:246] 
Both the International Monetary Fund and the World Bank have responded to the new circumstances with expanded programmes of 'adjustment' lending to the ldcs. In the case of the Fund, the multiple of a country's quota which may be borrowed for balance of payments support under a variety of arrangements has been increased, and the Fund is actively increasing its own borrowing for lending through its new facilities. The World Bank has likewise introduced a 'structural adjustment' lending programme designed for countries 'with the prospect of unmanageable deficits arising from external factors which are not likely to be easily or quickly reversed' [Wright 1980:21]. The constraint of the Bank's Articles is being overcome by regarding the new lending as an extension of programme lending 'in special circumstances'.

\section{Degrees of Conditionality}

What are the characteristics of these new programmes? And what are their likely implications for the borrowers?

The content of the new IMF lending has been succinctly summarised by the Fund's Managing Director:

in the period following the first wave of oil price increases approximately two-thirds of the resources provided by the Fund to its members were made available on terms involving a low degree of conditionality. At present, by contrast, some threefourths of our new lending commitments involve 'upper credit tranche' programs, that is, they require rigorous adjustment policies.

[J. de Larosière, in IMF 1981b:152]

The current structure of IMF facilities is set out in Table 1 . The only completely unconditional facility is the reserve tranche (ie purchase of a member's own quota subscription to the Fund); since unused quota can, in any case, be treated as part of a country's foreign exchange reserves this facility is of little further use in situations short of complete inability to pay for imports. The facilities of low conditionality are not uniform in their terms. For the buffer stock facility and the first 50 per cent of drawings under the compensatory financing facility (CFF) there is virtually no conditionality once a balance of payments need has been demonstrated. For the second 50 per cent of drawings under the CFF, a country must be 'cooperating' with the Fund to solve its balance of payments difficulties. First credit tranche programmes are of low conditionality in the sense that drawings are not normally conditional on performance, but they do contain objectives and performance targets which the borrower is expected to fulfil. Both the stand-by arrangement (the common means of access to the upper credit tranches) and the extended Fund facility (EFF) involve programmes of full conditionality, with access to periodic drawings-often quarterly - dependent upon strict fulfilment of agreed performance criteria. The stand-by arrangement is normally agreed for one year at a time and renewed as necessary. The EFF, on the other hand, envisages a three-year programme of lending and adjustment, usually with detailed annual programmes formulated within the extended framework, and with a longer repayment period. The EFF was first introduced in 1974; its introduction and subsequent expansion represent the Fund's chief response to the view that adjustment programmes might require periods longer than one year, and that extended loans for balance of payments support are needed in current international circumstances.

It can readily be seen that just under two-thirds of the Fund facilities potentially available to a borrower are now of high conditionality, even when the borrower is qualified to make full drawings from the low conditionality facilities. If a country has been badly hit by oil price increases, high interest costs, and domestic disruption, and yet has no buffer stock financing obligations and does not qualify for the CFF, then it is faced with a virtually immediate move into high conditionality facilities if it wishes to approach the Fund at all.

The transformation of the Fund into a lender of almost exclusively high conditionality is very recent. It was not characteristic of the international response to the first round of oil price increases in 1973-74, but derives from four developments in the structure of the Fund's facilities. First, quotas have not been increased sufficiently to keep pace with the growth of world trade, and there has been no increase in the multiples of quotas available in the form of low conditionality facilities. Second, the multiples of quotas available under stand-by or EFF have been substantially increased; when the EFF was introduced it added only 65 per cent of quota to total drawings that could be made. Third, the oil facility of 1974-76 has not been renewed. This facility was financed largely by OPEC subscriptions, and was available to support ldc balances of payments at very low conditionality. Fourth, the Trust Fund, inaugurated in 1976 for low-interest lending to ldcs from the proceeds of IMF gold sales, was fully disbursed by March 1981 . The Trust Fund facility was available at low conditionality, requiring a one year 'statement of good intentions' rather less onerous than that required for the first credit tranche.

All of these features would be of relatively minor importance if the proportion of Fund financing to total financing had continued to decline. This, however, has not happened. Under the programme of 'enlarged access', formally brought into operation with the Saudi 
table 1

International Monetary Fund facilities mid-1981

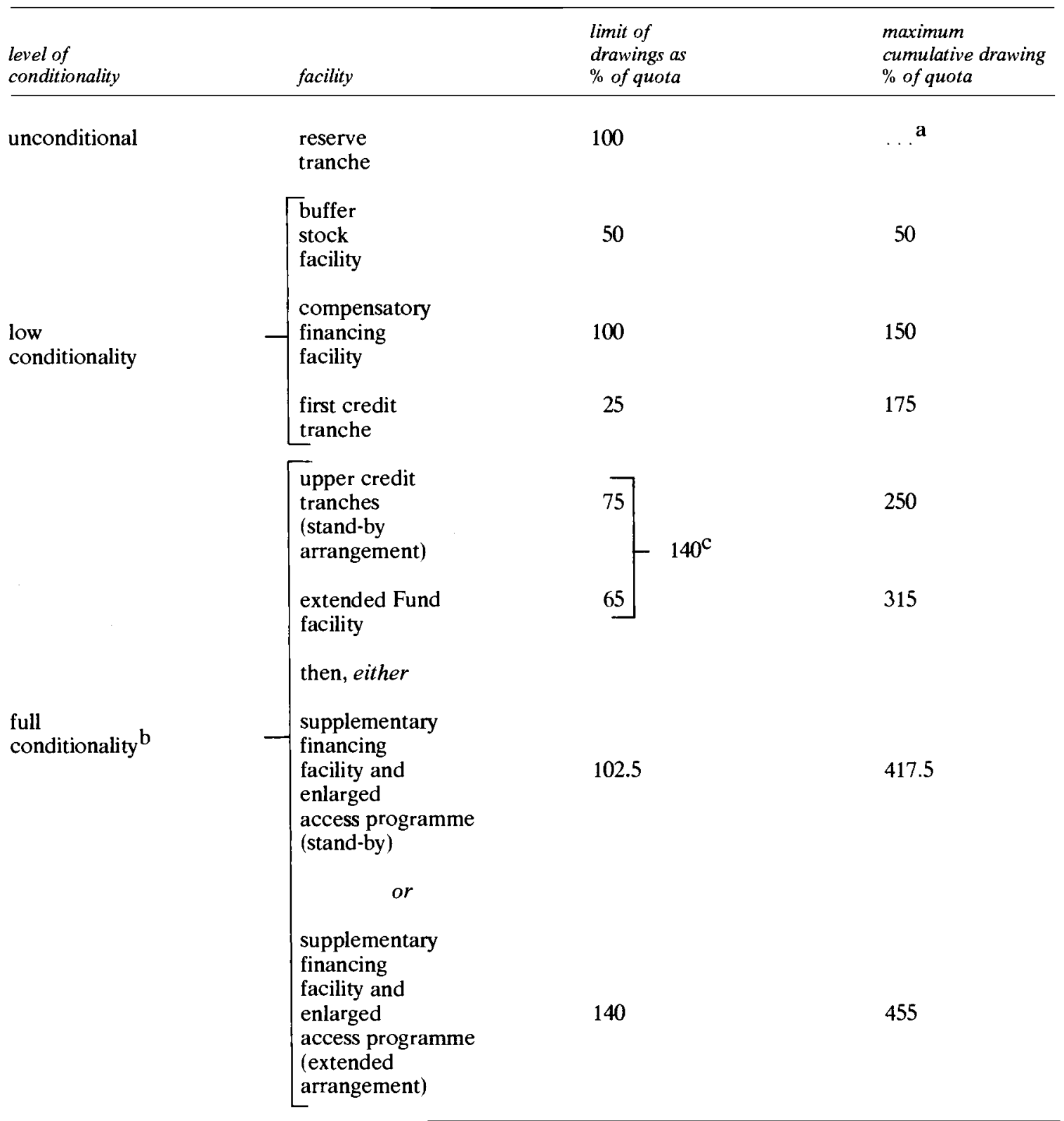

a. Since the reserve tranche can be counted as part of reserves, whether drawn or not, it is not included in the cumulative total of additional facilities available.

b. The Fund retains discretion to increase the multiples available under stand-by and extended arrangements, total outstanding amounts will not normally exceed 600 per cent of quota.

c. Combined total if upper credit tranches are foregone in favour of EFF.

Source: International Monetary Fund 1981d 
Arabian loan in May 1981, the Fund expects to make new lending commitments of the order of $\$ 20-25$ bn over the next three years. Thus, in circumstances of increasing need and possibly declining proportionate access to private credit, the conditionality of Fund facilities will assume still greater relevance for ldcs. It hardly needs emphasising that this will matter most to the poorest countries, and to those countries which require IMF facilities and programmes to maintain their credit-worthiness in private markets.

The new development in World Bank lending is complementary to trends in Fund facilities. Structural adjustment lending will be financed out of the general growth of Bank and International Development Association (IDA) resources, so that it is to a large extent a substitute for normal project lending. The new programme introduces a concept of explicit World Bank 'conditionality' for the first time. It is not given this name, but structural adjustment programmes require that:

a country must be willing to adopt appropriate changes in its policies and programs to enable its economy to adapt over a reasonable period to changes in the international environment without sacrificing its long-term growth objectives.

[Wright 1980:21]

The components of such a programme are likely to include efforts to ensure that the current account balance of payments deficit in the medium term is commensurate with the expected level of capital inflow, and strong emphasis on measures to improve productive efficiency. There may be components dealing with individual sectors (particularly agriculture and energy), with the allocation of public investment, and with the structure of incentives; there appears to be a growing emphasis on the dismantling of trade controls. There is thus an obvious aspect of complementarity with Fund programmes.

The Bank argues that 'prior recourse to the Fund's facilities is not a prerequisite for structural adjustment lending' [Wright 1980:22]. Nevertheless, since such lending is intended to be triggered by identified balance of payments difficulties, it seems unlikely that the Bank will conclude a structural adjustment programme with a country that either has no need of Fund facilities, or is unwilling to approach the Fund. It is thus also likely that the conditionality involved in Fund and Bank programmes will be consistent; indeed a Bank staff member has written that the Fund is guided by the Bank on development matters; the Bank is guided by the Fund on BOP adjustment' [Wright 1980:22].

\section{Conditionality - Issues and IMF Responses}

The issues of conditionality in the adjustment programmes required for balance of payments lending can be broken down into four elements: the economic theory and analysis informing the programmes, the period of adjustment, the scope of the programmes and performance criteria established. Despite the fact that the body of economic theory underlying Fund conditionality clearly shapes the Fund's approach to the other three elements, it is a striking feature of much of the literature on conditionality (particularly the critical literature) that the theoretical basis is largely ignored while the other three elements are subjected to detailed scrutiny. The most notable exception to this generalisation is the UNCTAD study [Dell and Lawrence 1980].

The criticisms of IMF programmes on grounds of their allowed adjustment periods, scope, and performance criteria are well known. And the Fund can reasonably claim to have taken action on all three counts in response to such criticism.

In lending programmes from the upper tranches prior to the 1973-74 round of oil price increases, a stand-by facility was normally accompanied by a one-year adjustment programme. In other words, the full burden of achievement of a balance of payments position acceptable to the IMF had to be borne in one year. Stand-by arrangements have subsequently envisaged the possibility of up to three successive one-year programmes, while the EFF is explicitly designed as a three-year programme. There is now greater flexibility over the volume of funds available from stand-by arrangements and EFF, while the Fund has also lengthened possible repayment periods.

An internal review of Fund conditionality guidelines in 1978 resulted in the announcement of revised guidelines on March 2, 1979 [see IMF 1979:82]. The new guidelines addressed both the scope of Fund adjustment programmes, and performance criteria.

In the past, Fund adjustment programmes have been regularly criticised on the grounds that they ignored long-term development objectives, especially growth and distribution issues, while emphasising short-term stabilisation and balance of payments equilibrium objectives. This, it has been argued, has proved costly in terms of disruption to national development efforts and worsening of income distribution, with no countervailing gain from lasting stabilisation achievements. The Fund has also been criticised for failing to differentiate among the causes of balance of payments disequilibria, and thus for failing to address important reforms of policy changes that might contribute to successful adjustment. The Fund's response 
to such criticisms has been to include the following item in its new guidelines:

in helping members to devise adjustment programs, the Fund will pay due regard to the domestic social and political objectives, the economic priorities, and the circumstances of members, including the causes of their balance of payments problems.

[IMF 1979:82]

The Fund already distinguishes between deficits which are short-term and self-correcting (ie cyclical and eligible for CFF support) and those which are 'structural' and chronic, requiring programmes of adjustment supported by stand-bys or EFF. In practice, however, there is no further distinction, within the 'structural' deficits, between those which have internal causes and those which are of external origin.

The Fund has also given renewed emphasis to 'supply management and the structural problems of members' [IMF 1981 c:3] and the Managing Director himself has stressed that, in addition to addressing problems of demand management, the Fund 'now systematically emphasise(s) the development of the productive base of the economy' [quoted in IMF 1981 c:2].

The performance criteria of IMF programmes are the quantitative targets for macro-economic variables, such as the level of domestic credit or foreign borrowing, which a country is required to meet if the programme is to be fulfilled and further instalments of Fund credit are to be released. These have been criticised on grounds of rigidity, narrowness and, sometimes, of irrelevance to the development problems of a particular country. In this case, the Fund's response has been to stress the potential flexibility of the criteria, and to argue that restriction to quantifiable macro-economic variables minimises the degree of interference with a country's domestic distributional or other priorities. The Fund has gone so far as to assert that:

the impact of Fund-supported programmes on other economic variables, such as income distribution, employment, and social services, depends on the manner in which the relevant policies are implemented. Decisions on the detailed execution of policy measures are naturally the sole responsibility of the government.

[IMF 1981 c:2]

Given the manner in which much criticism of the Fund has been formulated, it is perhaps not surprising that the response has been of this order. It is the contention of this article that the features of Fundsupported adjustment programmes cannot simply be dismissed as the product of an ideological preference, or as the result of lack of recognition of social and distributional issues. They are more appropriately seen as deeply embedded in the dominant strain of economic analysis which is articulated within the Fund. Until this is recognised, and until a response is developed which, for each country, offers an alternative which can be convincingly placed alongside the Fund's analysis, it is unlikely that the general shape and impact of Fund conditionality will be greatly altered. To put the point another way: current international efforts to reform the international monetary system, and efforts to expand the access of the poorest countries to financing through multilateral institutions, must be complemented by substantial technical efforts to strengthen the macro-economic policy frameworks of the ldcs.

The Fund itself denies that its programmes are based upon a uniform approach to economic policy [IMF 1981c:21. The evidence of Fund literature, however, suggests, at the very least, that the approach described below is the main source of both programme emphasis and performance criteria. ${ }^{3}$ It may well be constrained in particular circumstances by the Fund's Articles, by the facilities at its disposal, and by local conditions; but it is hard to accept that actual programmes have been significantly influenced by alternative approaches to economic analysis. ${ }^{4}$

\section{Economic Theory and Fund Conditionality}

The theoretical approach to macro-economic policy employed by the Fund is formally known as the monetary approach to the balance of payments. The academic elaboration of this approach is usually associated with the University of Chicago, but its use and development within the Fund pre-dates significant modern academic input. According to the Fund's own volume of research papers on the monetary approach to the balance of payments [IMF 1977] the impetus towards its development within the Fund came from work on the payments problems of ldcs, especially those of Latin America, during the 1950s. In addition to the 'gap between problems that could easily be solved with the help of Keynesian tools and those frequently encountered by officials concerned with monetary and balance of payments questions' [IMF 1977:6], there were four motives adduced for use of new methods in work on ldc problems. First, there were statistical difficulties; statistics of monetary aggregates were more readily forthcoming than up to date and detailed national income accounts. Second, there were computing difficulties during Fund staff missions to foreign capitals:

\footnotetext{
${ }^{3}$ See, for example, the regular editions of IMF Staff Papers, and especially the Fund's own volume of papers setting out its staff contributions to development of the monetary approach [IMF 1977]. An interesting critical paper on the monetary approach by a Fund official [Blackwell 1978 | serves to confirm the dominance of the approach in Fund programmes.

${ }^{4}$ The contents of IMF programmes have been discussed in Killick [1980|, Dell and Lawrence | 1980] and in Beveridge and Kelly [1980].
} 
the monetary approach permits a meaningful approximate analysis of the relevant aggregates with the help of models that are small enough to be calculated with pencil and paper. [IMF 1977:6]

Third, it was claimed that with undeveloped capital markets and financial instruments, the impact of excess domestic credit creation upon the balance of payments was more 'obtrusive' in ldcs than in dcs. Fourth, it was observed that control of domestic credit was already relied upon as a major instrument of demand management and balance of payments control. In summary, according to the Fund itself, the monetary approach to income analysis and the balance of payments was developed and deployed for a series of contingent and practical reasons, not theoretical or ideological ones.

The best known exposition of the approach is probably that by the Fund's former Economic Counsellor and Head of the Research Department, J. J. Polak, who is now Executive Director for the Netherlands at the Fund's Board [Polak 1957]. Apart from the Fund's own volume of research papers on the subject [IMF 1977], there is a substantial academic elaboration of the model and its implications in Frenkel and Johnson [1976]. There is also a growing number of empirical applications of the model in ldc case studies, and one recent attempt at direct comparison between the results of the monetary approach and a simple Keynesian model for Kenya over the period 1963-73 [King 1979]. The fact that the approach has been, and continues to be, subjected to a great deal of empirical testing and subsequent elaboration is clearly one of its great strengths. In the absence of strong competition, its further acceptance by governments and international organisations seems likely.

The theoretical approach to macro-economic policy which underlies the Fund's stabilisation programmes is 'monetarist' in the sense that it takes changes in the money supply to be the primary determinant of changes in total spending. It is cast in nominal terms rather than real terms, and is formalised in terms of financial stocks and flows rather than real stocks and flows; it implies that changes in monetary aggregates have a direct impact upon the balance of payments and the level of nominal national income. The approach has, however, been elaborated in a different context from the monetarism currently being practised by a number of Western governments, and therefore has distinctive features which influence its application in ldcs. ${ }^{5}$ Most

${ }^{5}$ Strictly, by no means all IMF economists or exponents of a similar approach claim to be monetarists: "while there is still controversy about the role of monetarism in solving problems of inflation and unemployment, the monet ary approach - ail the proponents of which are not necessarily 'monetarists' in the narrower sense - has come to occupy a central role in the analysis of balance of payments problems' \{IMF 1977:2\}. obviously, it assumes limited development of capital markets and financial instruments, and therefore assigns a limited role to monetary policy per se. Instead of attempting to manipulate the 'supply of money', the approach concentrates on the rate of domestic credit expansion and thence upon aggregate fiscal policy. Since it is commonly argued that the private sector's demand for credit is either relatively low or more easily influenced by indirect methods (interest rates or taxation), the burden of credit adjustments tends to fall on the public sector. Thus monetary policy and fiscal policy do not run in opposite directions, as they have tended to do in Britain from 1979-81. It is from this component of the approach that the public expenditure cutting, tax-raising component of Fund programmes is derived, as is the setting of performance criteria based on such measures as domestic credit to government and public authorities.

In important respects, this amendment to dc monetarism would meet with the approval of a wide range of economists: both neo-classical and mainstream Keynesian economists would have little difficulty in agreeing that, with a given economic structure, price levels and levels of capital inflow, aggregate fiscal policy will determine the balance of payments outturn in a small open economy. If, for one reason or another, excess demand cannot be met from imports, then aggregate fiscal policy will also affect the rate of inflation. The argument begins over how to apply this generalisation to the process of balance of payments adjustment in individual countries.

More controversially, the model implies that an increase in exports (or a reduction in imports through import restrictions) will raise the money supply and nominal national income, but will not of itself correct a balance of payments deficit. Similarly, any increase in domestic credit creation, brought about, for example, by higher government spending will inevitably be translated into an equivalent loss of reserves. This is because the balance of payments is viewed as the monetary expression of the difference between total spending and total income, while increases in the money supply - whether through increased export earnings or domestic credit creation-will automatically result in increased spending (or outflows by other means if residents decide to hold funds abroad).

These conclusions are critically dependent upon the assumptions of the model, in particular that of a constant velocity of circulation of money and the absence of domestic leakages (such as forms of saving which do not lead to increased spending by anyone else). They do, however, explain why, according to the monetary approach, there is one and only one way 
to restore lasting balance in external payments irrespective of the source of the problem: demand deflation to achieve a reduction in the level of domestic credit. The approach acknowledges, however, that a faster rise in nominal income may make it easier to impose the measures necessary (eg higher taxes) to reduce domestic credit expansion and thus the balance of payments deficit. It also acknowledges that rises in nominal income (from export expansion/import restriction/credit creation) may become rises in real income 'depending upon the elasticity of supply' [Polak 1957:29].

There is thus room in the approach for measures to promote the growth of real income. In formal terms, however, the Fund's emphasis is normally upon promoting movements along the supply curve for particular goods rather than altering its position or slope. In practical terms, the Fund's methods of promoting growth with a sustainable balance of payments are dependent upon the interpretation of its Articles of Agreement. These Articles incorporate the view that free trade and the unhindered operation of markets are conducive to international welfare, whereas governmental controls on trade and intervention in markets have harmful effects. Thus the Fund does not encourage the use of quantitative restrictions on trade and payments (and tries, where possible, to have them removed), nor does it emphasise administrative, institutional or other forms of structural change to promote the expansion of exports. It is common in Fund programmes and public statements for the main emphasis to be given to the elimination of price distortions as the instrument for promoting growth while maintaining an acceptable balance of payments. The price distortions regularly involved are overvalued exchange rates and underpriced public sector services - in both cases the diagnosis of excessive real wages is often the main reason for the prescription. Reduction in real wages will assist in reducing the public sector deficit, and in improving the competitiveness of import-competing and export industries.

The 'removal of distortions' aspect of Fund programmes, and the rejection of direct controls as a means to reduce a payments deficit, can introduce a policy conflict which is difficult to resolve within the analytical framework of the monetary approach. It follows from the model that in a small open economy, the instrument with strongest effect upon the level of domestic prices is the exchange rate. If the domestic currency is devalued as part of a general deflationary or priceadjusting package the rate of inflation accelerates. The aims of the devaluation will only be achieved if nominal wage increases can be kept below the increase in the price level or (which amounts to the same thing) if productivity increases. These outcomes are dependent upon the structure of the labour market. In the meantime the only instrument which can have an immediate impact on the price level has been moved in an inflationary direction. The effectiveness of the policy choice, in its own terms, may often depend upon additional measures (trade union restrictions, for example) to achieve a reduction in real wages. The cost could be political and social disturbance, accelerated inflation or both-leading to the events graphically described by the Brandt Commission as 'IMF riots'.

\section{General Models and Particular Economies}

The success of programmes based upon the monetary approach to the balance of payments depends not only upon the theoretical validity of the model itself. It also depends upon the mechanism by which, within the model, adjustment of each variable to its new level takes place. On the one hand, this can be specified differently in different elaborations of the model (once we abandon the use of 'equilibrium conditions' in each case). On the other hand, the mechanism specified may be inaccurate in the context of a particular country, or the conditions of a particular time. For example, we need only to ask the following questions to appreciate the high degree of risk inherent in using a uniform model of economic adjustment over a range of different cases: What is the mechanism for transmission of domestic inflation? Can real wages be reduced? What is the cost? What determines the supply response of producers of various agricultural crops? Does a change in the exchange rate alter the relative prices of traded and non-traded goods?

When such questions are posed in this form, it is evident that substantial empirical research, not to mention sensitive political judgments, might well be necessary to answer the questions in a manner relevant to an individual country's economic policy.

Despite this, the monetary approach continues to be applied in a largely uniform manner. It is reinforced, on the one hand, by the ease with which it yields 'objective' performance criteria, and, on the other, by the absence of any real alternative that incorporates not only different objectives but also a different analysis of economic reality. To say this is not to deny that the monetary approach can yield useful insights in many cases. Nor is it to deny that programmes involving deflation, exchange rate adjustments, removal of subsidies and so on are sometimes necessary. The point is that while adjustment programmes may be required across a wide range of countries, there is no reason why they should each be largely uniform in content or based upon the same approach to economic analysis. 
Now that the role of the Fund and the Bank in recycling is being greatly enhanced and, as we have seen, the proportion of Fund and Bank finance that is disbursed with conditionality has been radically increased, the content of conditionality has assumed fargreater importance than it had in the past. If, as has been argued here, the theoretical basis of Fund conditionality remains largely unchanged, then the possible implications for the re-cycling process are serious.

As has happened in the past, countries may simply refuse to approach the IMF for assistance or may suspend programmes before completion if they judge the required conditionality to be unacceptable. A variety of countries have adopted this position from time to time, including Brazil, India, Ivory Coast, Jamaica, Tanzania and Kenya. Even though almost all the countries listed have subsequently agreed or requested further programmes with the Fund, the issue of conditionality has meant that these countries have followed financing and adjustment patterns which might not have been their preferred or best approach.

The Fund itself has complained that countries often make a request for assistance only at the last possible moment - when the balance of payments position has deteriorated to an extent that requires a severe adjustment programme. The Fund argues that conditionality would be less burdensome if countries were to discuss a possible programme as soon as the onset of a balance of payments problem is perceived. A vicious circle has thus been created: because countries are wary of conditionality, they approach the Fund only when they have run out of alternatives and are too weak to resist a severe programme; it then appears internationally that only countries in dire straits approach the Fund, and that a severe adjustment programme is an automatic accompaniment of Fund lending. Until the circle is broken, it is difficult to envisage successful recycling and adjustment via the Fund.

Because the balance of payments positions of a large number of countries are already extremely serious, it is possible that more countries will be forced to have recourse to the Fund, irrespective of their views on conditionality. Indeed, during May 1981 the Fund's Managing Director stated that the Fund currently has economic programmes with 32 member countries, compared with an annual average of 10 during the years 1974-78 [IMF 1981b:152]. The risk is therefore increased that, if conditionality continues to be imposed in the familiar manner, more countries will either fail to meet the performance criteria and lose access to Fund resources, or will meet the criteria at heavy cost to their economies and societies in other respects.
Detailed descriptions of cases in which this has occurred in the past are contained in Dell and Lawrence [1980].

In order to break out of the vicious circle, and to make the new Bank/IMF recycling a potential success, there is a strong case for change in the basis of adjustment programmes. If this cannot be achieved, then it is likely that the call for an international financial alternative to the IMF, with greater ldc influence, will be strengthened-only to meet with resistance again from the 'North' and thus a further impasse.

\section{Prospects and Possibilities}

The Fund itself devotes a great deal of effort to examining, refining and testing its own approach. It is now necessary to broaden the scope of these inquiries, both by bringing alternative approaches to bear on stabilisation problems (as the Fund already claims to do, but with little evident result in its programmes), and by conducting the debate in more varied forums and at different levels of technical sophistication. Without stepping too far outside the framework of the monetary approach to the balance of payments, it would be possible for certain key aspects of the model to be tested more critically.

For example, the monetary approach divides the 'base' of the money supply into two components: foreign reserves and domestic credit. When foreign reserves fluctuate with balance of payments changes, it is assumed that the domestic money supply will also fluctuate and can only be controlled by expansions or contractions in credit creation. No allowance is made for the possible use of direct methods (such as stabilisation funds) to 'sterilise' new foreign earnings, spread their monetary and fiscal impact over time, and permit a stable trend of domestic credit growth instead of a counter-cyclical one. Are these presumptions correct?

How stable has the velocity of circulation of money in ldcs been in recent years? And has there in fact been a stable relationship between growth of the money supply (according to some relevant measure) and changes in nominal income? What is the effect of the diversification of financial markets and instruments upon the model and derived performance criteria (and on the definition of the supply of money)? Are supply elasticities commonly found to be such that an increase in demand will affect prices and/or the balance of payments, rather than output? Different answers to these questions from those currently implicit in the design of Fund programmes would clearly have farreaching effects. 
But if the wider requirements of ldcs and critics of the Fund are to be met, it will be necessary to go a good deal further than is implied by the empirical testing of a model of the monetary approach. Dell and Lawrence [1980:72] describe the Kenyan experience of combining World Bank and IMF lending in a programme that attempted to link short-term stabilisation policy with longer-run goals for economic development. The programme was not completed because agreement was not reached between Kenya and the Fund on the budgetary aspects of the annual programme for the second year of an Extended Fund Facility. It also involved complicated three-cornered negotiations which were extremely demanding on the time and technical resources of an ldc government. Nevertheless, it provides an indication of future possibilities. The important question is whether these possibilities can be successfully developed while the Fund adheres to programmes based on the monetary approach.

In addition to questions about the validity of the model itself, the Fund's deployment of it has four further problematic features. First, the content of programmes is remarkably uniform in an increasingly diverse world. Second, the Fund argues that the programmes are in principle neutral with respect to income distribution issues, and that distribution is only affected by governments' choices over the manner of implementation. Third, although the Fund now emphasises the importance of growth, it restricts the promotion of growth to 'supply management' and, in turn, concentrates upon manipulation of a rather blunt range of instruments (eg the exchange rate) to provide the correct price signals for improvement of supply conditions. Fourth, it is often alleged that Fund programmes involve a shift of resources from public to private sectors, irrespective of the goals of the countries concerned. If this is true, it is reinforced by the Fund's theoretical approach, given the vital role assigned to public sector borrowing and elimination of price distortions. In other words, there is at present very limited scope for programmes tailored precisely to the structural characteristics and development objectives of individual countries; there is no scope for incorporation of quantitative distributional criteria, and there is almost no recognition that increased production may be constrained much more by structural or administrative problems than by price distortions.

Can the ldcs themselves provide an alternative? In some cases the answer in the short run must be no. There are countries whose need for finance is now so desperate that the conditions upon which it is made available seem almost irrelevant. There are also countries whose political, institutional or administrative capacity for macro-economic management is severely limited. In these cases, the burden of providing finance and providing it on suitable terms, lies outside-and particularly with the IMF.

But an approach built solely around the short-term requirements of the desperate cases is not a satisfactory one for the rest of the world, or in the longer term. If an administration is presumed capable of carrying out an IMF-approved programme of adjustment, it is reasonable to suggest that the same administration could formulate its own programme-perhaps with some assistance from sympathetic outsiders and international organisations. If ldes could do this, and obtain financial support for such a programme from either private lenders or official sources or both, then the way would be open to invite the Fund and the Bank to support such programmes too. In a manner of speaking, this is what Brazil has been doing for some years. Peru explicitly attempted such an arrangement with private lenders in 1976, but the programme broke down after a short period.

Although the Fund, again, states that it favours applications from countries with programme proposals of their own, the unfortunate reality is that if a possible programme is discussed with the Fund and agreement cannot be reached, international banking circles are likely to know that the attempt has failed and to mark down the 'credit-worthiness' of the country concerned. Hence, countries with their own clear ideas about adjustment priorities are doubly reticent about approaching the Fund.

The efforts of ldcs in this direction would have a greater chance of success if individual countries (and development economists) paid more systematic attention to the linkage between macro-economic stabilisation policy and development strategy, and organised the first explicitly to support the second. ${ }^{6}$ This requires, first, that the development effort be sustainable over time provided that the stabilisation framework remains intact and estimates of external developments (prices, capital flows) do not prove wildly wrong; and, second, that the assignment of instruments to targets in macroeconomic policy should be such that it is clear which instruments must be manipulated in order to cope with an external shock. In the past, development economists (and development plans) have been preoccupied with the allocation of resources among potential users - originally among productive investments, more recently, too, among social groups - and also with the 'mobilisation' of resources; there has been less interest in the domestic mechanics of how that 'mobilisation' is sustained over time so that the chosen allocation can have practical effect. That is the role of a macro-economic stabilisation framework.

${ }^{6}$ For an account of an attempt to do this, see the Papua New Guinea case in Garnaut 1981, forthcoming. 
This is not intended to suggest that international economic developments do not have dominant impact on the options open to ldcs. Nor is it intended to disregard the 'asymmetry of adjustment', ie the fact that the burden of adjustment falls on the deficit and not the surplus countries, but this issue is beyond the scope of this paper. It is rather to argue that macroeconomic management matters as much as development planning if there is to be any room for manoeuvre at all. It is also to suggest (as undoubtedly the Fund would agree) that a short-term programme of macroeconomic management is not only needed when a crisis is at hand and it must be called an 'adjustment programme'; it should, instead, be an integral and continuing component of development planning.

Beyond this, it is unlikely that Fund programmes will take explicit account of income distribution issues, or of structural constraints on economic growth, until the ldcs themselves link these to development planning and place them firmly on the agenda for discussion. In the case of income distribution, this requires both quantitative targets, (perhaps in the manner suggested by some elaborations of the 'basic needs' approach) and an understanding of how the manipulation of macro-economic instruments, the tax burden, and public expenditure affects distribution. On the removal of domestic structural barriers to new output (eg land reform, or overhaul of agricultural extension services), there is no international substitute at all for the programme of an ldc government. In both cases, the World Bank could wield a positive influence; but the linkage between structural adjustment lending and IMF programmes once again brings back the limitations of the monetary approach to the balance of payments.

It may be objected that what is proposed here is no more than has always been necessary, but has proved elusive either because of international disruption, or because of conflicting interests within ldcs themselves. True-but unless a constructive critique of the monetary approach to the balance of payments and its application is now mounted, and alternative adjustment programmes are urgently propounded by ldes, it is probable that the new recycling round will be considerably less satisfactory from the perspective of the ldcs than even the chequered experience of the 1970s.

\section{References}

Bank of England, 1981, Quarterly Bulletin, vol 21 no2, June

Beveridge, W. and M. Kelly, 1980, 'Fiscal Content of Financial Programs supported by Standby Arrangements in the Upper Credit Tranches', IMF Staff Papers, vol 27 no 2, June

Blackwell, C. P., 1978, 'Monetary Approach to Balance of Payments Needs Blending with Other Lines of Analysis', IMF Survey, 20 February and 6 March

Dell, Sydney and Roger Lawrence, 1980, The Balance of Payments Adjustment Process in Developing Countries, Pergamon/United Nations, New York

Frenkel, J. A and H. G. Johnson (eds), 1976, The Monetary Approach to the Balance of Payments, Allen and Unwin, London

Garnaut, Ross, 1981 (ed), Macro-economic Policy in a Small Developing Economy: Theory and the Papua New Guinea. Experience. Institute of Applied Social and Economic Research, Monograph, Port Moresby, forthcoming

Griffith-Jones, S., 1980a, 'The Growth of Multinational Banking, the Eurocurrency Market, and their Effects on Developing Countries, The Journal of Development Studies, vol 16 no 2, January

$-1980 \mathrm{~b}$, 'Adjustment experience in the 1970s', paper for a Commonwealth Secretariat seminar on adjustment policies, IDS, November

- 1981, 'The Saudi Arabian loan to the IMF', mimeo, IDS, June

International Monetary Fund, 1977, The Monetary Approach to the Balance of Payments, a collection of research papers by members of the staff of the International Monetary Fund, Washington DC

- 1979, IMF Survey, Washington DC, 19 March

- 1981a, World Economic Outlook, Washington DC, May

- 1981 b, IMF Survey, Washington DC, 18 May

- 1981 c, IMF Survey: Supplement on the Fund, Washington DC, May

- 1981d, International Financial Statistics, Washington DC, July

Killick, Tony, 1980, 'The IMF and the Third World', Overseas Development Institute Briefing Paper, London, October

- 1981, 'Eurocurrency market recycling of OPEC surpluses to developing countries: fact or myth?' in Christopher Stevens (ed), EEC and the Third World: Survey I, Hodder and Stoughton for ODV/IDS, London

King, J. R., 1979, Stabilization Policy in an African Setting: Kenya 1963-1973, Heinemann, London

Polak, J. J., 1957, 'Monetary analysis of income formation and payments problems', IMF Staff Papers, vol VI; reprinted in IMF 1977

Wright, E P., 1980, 'World Bank lending for structural adjustment', Finance and Development, February 